\title{
Holy Selfies: Performing Pilgrimage in the Age of Social Media
}

Nadia Caidi, University of Toronto

Susan Beazley, University of Toronto

Laia Colomer Marquez, Universidad Iberoamericana

\begin{abstract}
In this article, we examine the selfie-taking and sharing practices of Muslim pilgrims in Mecca, Saudi Arabia. We introduce the concept of the "holy selfie" (a selfie taken during either the Hajj or the Umrah pilgrimages) and report on a visual content analysis of a sample of 100 holy selfies publicly available on social networking platforms. We seek to reach an understanding of the work that holy selfies do in the context of the expressions of spiritual and religious identity of those producing them. Our findings suggest that the embodied experience of pilgrims at the holy sites finds an expressive release through holy selfies, with many pilgrims viewing selfie-taking as an important part of their journey. The selfies (and associated features) capture and document pilgrims' experiences, contribute to their meaning-making, enable the sharing of memories with loved ones, and attract online followers. Our study provides a picture of how holy selfies blur the gender line (as many males as females take them), emerge despite the opposition of Saudi authorities, and serve as a means of engaging with a multiplicity of audiences. We seek to start a conceptual and methodological conversation about this emerging phenomenon of identity construction involving the use of new media along with the construction of affiliative identities among geographically dispersed communities of Muslim pilgrims. The taking of holy selfies can thus be read as a tactic used by 21st-century Muslims to create opportunities for self-representation and community building in a context of increasing Islamophobia.
\end{abstract}

Keywords: everyday religion; Hajj; Islam and Muslims; pilgrimage; representation; selfie; social media

Publication Type: research article

\section{Background and Context}

$\mathrm{E}$ ver since smartphones started featuring a front camera, we have seen the rise of the selfie, an image of oneself (usually alone, but possibly with others too) taken with one's smartphone and shared with others through posts on social media platforms. Taking and sharing selfies is an easy, popular, and common practice that has become increasingly widespread since late 2012. Based on the frequency of use of the hashtag \#selfie, Twitter declared 2014 to be "the year of the selfie" (Ng, 2014). The Pew Research Center (2014) reports that $55 \%$ of millennials (those born between 1981 and 1996) have posted a selfie on social media, compared with $24 \%$ of Gen Xers (those born between 1965 and 1984). Indeed, selfies seem to be 
a global phenomenon in youth and popular culture (Meikle, 2014; Senft, 2013; Senft \& Baym, 2015). They have been characterized as "an emerging sub-genre" of self-portrait photography (Tifentale, 2014, p. 8) distinguished by the ability to immediately distribute the self-portraits via social media platforms (Instagram and Twitter, for instance) along with the content that may be attached to the selfie (e.g., metadata, captions, comments, likes; Tifentale \& Manovich, 2015). Other sub-genres of selfies have been identified online and in the popular media. Examples include selfies taken in front of a mirror (Eler, 2013), "after sex" selfies (Hudson, 2014), and "celebrity" selfies (epitomized by the Ellen DeGeneres group selfie taken during the 2014 Oscars, which, as of July 2015, attracted over 3 million shares/retweets).

While selfies are not usually linked to the sphere of spirituality and religion, a Google search on "selfies and faith" easily retrieves thousands of such selfies, from Pope Francis posing for group selfies to selfies shared by the Dalai Lama to selfies of individuals completing various pilgrimages, such as Lourdes in France or in Jerusalem.

In this article, we examine the annual Islamic pilgrimage to the holy city of Mecca in Saudi Arabia (referred to as the Hajj). This pilgrimage is a pivotal, transformational moment in the social and religious life of Muslims. In 2016, 1.86 million pilgrims performed Hajj, 71\% of whom came from outside of Saudi Arabia ("Saudi Arabia," 2016). For many Muslims, the pilgrimage is a once in a lifetime experience. In fact, it is obligatory for Muslim adults who are financially and physically able to attend the Hajj at least once in their lifetime, as it is one of the five main pillars of Islam. The Hajj is performed at a specified time every year during the 12th month of the Muslim lunar calendar. During the Hajj, millions of Muslim men and women congregate in Mecca to carry out set rituals at a series of locations, with the aim of absolving themselves of sins (Bianchi, 2004; Porter, 2012). In addition to the Hajj, Muslims may also participate in the optional pilgrimage to Mecca known as the Umrah. The Umrah can be undertaken at any time of year and includes some of the rituals performed during the Hajj; however, it does not require wearing the specific (ihraam) garbs or performing some of the Hajj's final rituals.

Although the purpose and meaning of the Hajj have presumably not changed over time, the experience of it has, as modern life and pilgrimage have intersected. The 21 st-century Hajj, or "pilgrimage 2.0" (O'Connor, 2014), takes place under the shadow of towering cranes, evidence of the widespread infrastructural and commercial development occurring in Mecca. While there has always been tension between consumerism and spirituality in the context of all pilgrimages, including the Hajj (Bianchi, 2004; Edensor, 1998; Porter, 2012; Qayyum, 2014), this tension takes on new forms as today's pilgrims are immersed in WiFi and apps. Pilgrims can now tweet, blog, and post photos of their Hajj experiences as they unfold. Although some Hajj tour operators and websites providing advice to Hajj travelers recommend leaving technologies such as smartphones at home in order to truly detach from the world and to achieve greater spiritual and mental calm, many Hajj pilgrims are not heeding those recommendations, choosing instead to use those technologies to stay connected, document their experience, and facilitate their rituals (Gani, 2015; Guessoum, 2011; Janmohamed, 2016).

The importance of information sharing as testimonial ("I was there") and as a means of documenting one's journey is not new (Porter, 2012); yet, these emergent social media practices are significant in the context of contemporary expressions of spiritual and religious identities in Islam, along with the vivid debates they raise. In this article, we seek to understand the role that selfies play in the context of the spiritual and/or religious experiences involving the Hajj and the Umrah. We selected the term "holy selfie" rather than "Hajj selfie," as we refer to selfies taken both during the Hajj and the Umrah (the "lesser" pilgrimage to Mecca). Our visual and content

The International Journal of Information, Diversity, \& Inclusion, 2(1-2), 2018

ISSN 2574-3430, publish.lib.umd.edu/IJIDI/ 
analysis of a sample of selfies was aimed at reaching an understanding of this specific sub-genre of selfies: What are some of the defining features? What do these holy selfies convey about the nature of the experience for the selfie-taker and for the viewer? What can be discerned about the expressions of spiritual and religious identity of the selfie-takers and consumers?

Our findings are based on a content and visual analysis of 100 holy selfies and point to an emerging global phenomenon that is symptomatic of the pervasiveness of technology in our everyday life, including in spiritual and religious experiences. In addition to documenting one's spiritual journey, holy selfies also contribute to our reflections on the performance of pilgrimage and on what it means to be a Muslim in the 21st century, especially given the diversity of the Muslim world and of Muslim experiences and practices (in "Refiguring Islam," Nada Moumtaz, 2015, discusses the complexities of defining Islamic "tradition" [and its coherence] and points to emerging scholarship in the anthropology of Islam that reexamines Islamic tradition through the lens of practice, embodiment, effect, or ethics). As Appadurai (1986) reminds us, objects have a social life, and one must be aware of the (competing) regimes of value within which objects circulate. As "residues of performances" and "agency in object form" (Boutcher, 2013, p. 155), holy selfies open up a space for reflection on this emerging phenomenon of identity production involving the construction of affiliative identities among geographically dispersed communities of pilgrims who use new media as a means of documenting and sharing their pilgrimage experiences. We argue that, beyond pilgrimage, holy selfies also speak to the experiences of being a Muslim in a post-9/11 world. Speaking of the Canadian Muslim diaspora (although this is true for Muslim diasporas elsewhere), Zine (2012) notes that it is "a complex, contradictory, and hybrid space filled with a mix of liberatory possibilities and productive tensions" (p. 2). In this space, Muslims' relationship to themselves and to non-Muslims is a perpetual work in progress, ridden with concerns around policing and integration and around proving the kind of Muslim one is (Bhimani, 2013). Holy selfies have a place in this conversation about what it means to be a Muslim today: They point to a moment in the lived experiences of a Muslim (as they embrace their faith and embark on this religious/spiritual journey), but they also serve as intimate traces left behind by Muslim people on social media platforms for multiple audiences to see.

\section{Affiliative Identities and Object Agency}

After Saudi authorities lessened restrictions on camera phones at the Hajj, social media sites saw an increase in posted selfies taken during the Muslim pilgrimage. By 2014, the hashtag \#hajjselfie was trending on Twitter (Heng, 2014), and global media outlets were reporting widely on the Hajj selfie and the controversies surrounding it (AFP, 2014; Aneja, 2014; Keen, 2014; Quraishi, 2014). It must be noted that photography and video recording have traditionally been prohibited in the holy sites during pilgrimage. The Hajj is a time when the memory of Abraham is strong, as both the Hajj and the festivity cloturing it (the Eid al-Adha) commemorate events in Abraham's life, in particular his opposition to idols (which used to be housed and displayed in the holy site of the Kaaba [Mecca] before the rise of Islam). As part of this Islamic debate on the representation of living beings (Grabar, 2006; Gruber \& Shalem, 2014; Gruber, 2009), the rising incidence of selfie-taking and live Snapchat streaming during the Hajj pose new challenges for Saudi authorities (Gani, 2015; Janmohamed, 2016; Lattouf, 2014). Whereas the authorities could easily confiscate a camera or a video-recording device, it is harder to confiscate smartphones, as they are easier to conceal and are needed for purposes other than filming.

Serving as a testimony of the pilgrim's important religious act, the holy selfie presents the Muslim pilgrim against the background of religious icons, a non-intrusive and considerate way to record

The International Journal of Information, Diversity, \& Inclusion, 2(1-2), 2018

ISSN 2574-3430, publish.lib.umd.edu/IJIDI/ 
memories and share the experience with family and friends. However, recent developments have also pointed to the symbolic and political nature of selfie-taking. For some, the practice of taking selfies during the Hajj is viewed as disruptive to others and counter to the spirit of modesty and worship that defines the Hajj (Blumberg, 2014). In its coverage of Hajj selfies, Arab News reported that some scholars and pilgrims view Hajj selfies as "touristy behaviour" and a form of bragging (AFP, 2014). While some Islamic scholars reportedly believe that non-essential photography should be prohibited at the Hajj, others believe that only photos intended for distribution need to be prohibited (AFP, 2014; Hazaimeh \& Waha, 2014; Quraishi, 2014). As Moumtaz (2015) asks, "[H]ow is the coherence of a tradition sustained? What are the conditions that make certain practices in the tradition debatable and certain questions thinkable? Who are the authorized speakers of the tradition?" (p. 141). As selfies (of any type, not just at pilgrimage sites) became a phenomenon, several Muslim clerics spoke out against them. Some clerics in India have call selfies "un-Islamic" and prohibit women and girls from posting them online; this prohibition is based on the edict that showing a woman's face to unknown and unrelated men is unacceptable (Fores, 2013). A cleric in Indonesia, Felix Siauw, has declared selfies a sin under Islamic law, in particular calling out female Muslim selfie-takers as shameless (Thornhill, 2015). It must be noted that Muslim women have responded to these declarations using the very tools that are being condemned (Muchinsky, 2015). The backlash to Siauw's fatwa included a flood of selfies posted with the hashtag \#Selfie4Siauw. Bloggers also took to the Internet to express their opinions, as epitomized by the magazine MuslimGirl, which published a tongue-in-cheek response to Siauw; that response included guidelines to help Muslim girls take a perfect selfie (Shannon, 2015). Other examples of Muslim women radically embracing the selfie can be found elsewhere online. Images of the Iranian reporter Masih Alinejad, who posted a selfie that showed her driving in Tehran while not wearing a hijab and a photo of her smiling and jumping in the air in England, went viral and women began sending photos to Alinejad that showed them without their hijab. Alinejad responded by creating a Facebook page and an online social movement/campaign website called My Stealthy Freedom where women can share selfies and other photos of themselves without wearing a hijab (Ladybits, 2014). Those who view Muslim women as marginalized, stereotyped, and underrepresented on the Internet see a role for selfies in positively shaping Muslim women's representation.

Media and scholars have diverging views on the selfie ranging from negative to neutral to positive. On the less flattering end of the spectrum, selfies are viewed as cries for attention or affirmation (Agger, 2012; Mehdizadeh, 2010; OUPBlog, 2013; Ryan, 2013; Tifentale, 2014), as vanity or exhibitionism, as self-absorption (Warfield, 2014), or as an expression of narcissism (Fox \& Rooney, 2015; Keen, 2014). Some of these views may be encouraged by research into social media use in general, which has found a correlation between higher levels of narcissism and extroversion with greater online activity (Fox \& Rooney, 2015; Mehdizadeh, 2010; Panek, Nardis, \& Konrath, 2013; Ryan \& Xenos, 2011). Research that asks selfie-takers about their motivations tends to place the selfie in a more positive light, whereby selfies are cast as a form of selfexpression or self-representation (Kwon \& Kwon, 2015; Murray, 2015; Tifentale, 2014; Warfield, 2014), self-exploration or self-reflection (Fausing, 2013), or a tool that allows one to exercise control over one's self-image and identity (Cep, 2013; Wang, 2012).

Holy selfies, like most selfies, are at the intersection of the private and the public, the individual and the communal (Freedland, 2013; Murray, 2015; Senft \& Baym, 2015; Tifentale, 2014). From the selection of the location of the selfie, to the camera angle, to the subsequent editing (of the picture as well as the hashtags and captions that accompany it), holy selfie takers clearly intend for their pictures to be viewed and publicly consumed. In that respect, selfies are another way

The International Journal of Information, Diversity, \& Inclusion, 2(1-2), 2018

ISSN 2574-3430, publish.lib.umd.edu/IJIDI/ 
to satisfy our human need to connect with others. Holy selfies add a unique dimension in that they can be construed as a manifestation of everyday lived religion (Hall, 1997; Dessing, Jeldtoft, Nielsen, \& Woodhead, 2014; Streib, Dinter, \& Soderblom, 2008), particularly in a technologydriven world. Indeed, network-based communication technologies pervade everyday lives, especially with the ready availability of the Internet through mobile devices, including many developing nations where the penetration of mobile phones greatly outweighs that of personal computers. Social media platforms are providing new spaces where individuals can negotiate and express their spiritual and religious identities and engage in "doing" religion away from the broader politics of religious practice (Hall, 1997; Dessing et al., 2014; Streib et al., 2008).

In the aftermath of 9/11 and the ongoing "war on terror," Muslims seem to be cast either as the "enemy within" (Bhimani, 2013; Caidi \& MacDonald, 2008; Kellner, 2003; Thobani, 2003; Zine, 2012) or as the co-opted subjects of the likes of the Islamic State (ISIS), whose sophisticated uses of social media to produce and disseminate images and videos (including the infamous executions and destruction of artifacts) purports to represent Islam and speak for Muslims. What is less clear is how wide a range of Muslim voices is being represented and heard. Bhimani (2013) posits that the focus of scholarship by or about Muslims in the public domain since $9 / 11$ often has been "on the isolation and detention of Muslims who pose a threat to the state, their lack of integration, Muslim accommodation, paternalistic intervention and concerns on Muslim women's bodies" ( $p$. 18). Muslims' relationships to the state, to each other, and to non-Muslims seem to be under constant scrutiny. Images of Muslim people circulated post-9/11-as victims of the turmoil, as threats to wider society, or as political fundamentalists-contribute to reproducing certain stereotypes (Bhimani, 2013; Hirji, 2006; Razack, 1998; Thobani, 2003; Zine, 2012). The modern orientalist allegorical subjects that are thus produced serve to justify the management and ostracizing of Muslims post-9/11 (Bhimani, 2013). Imagery as an instrument of imperialism has been well documented. Makhoul (1998) recounts the production of postcards by European photographers based in North Africa and the Middle East in the 1930s that sought to depict images of the Orient. These postcards were circulated by mail to the West with the purpose of standing as photographic proof of the "imagined corruption of the people of the East" (p. 45). According to Bhabha (2007), "the productivity and circulation of subjects and signs are bound in a reformed and recognizable totality" (p. 371). The postcard status as a repetitive, mechanically reproduced, traveling body systematically embodied the fixation of the Oriental stereotype. Much like the medium of the traveling postcards, post-9/11 circulated images of Muslim people (i.e., the dangerous Muslim man and the imperiled Muslim woman) reproduce similar stereotypes (Bhimani, 2013; Echchaibi, 2013; Thobani, 2003; Zine, 2012).

The holy selfie resembles a virtual self-produced postcard to be shared with others across the world. While shedding light on individual Muslims' spiritual journey and depicting everyday Muslims in their lived practice of Islam, these selfies also enable the individual to consort directly with fellow Muslims and non-Muslims alike without any interference or intermediation. This function is close to Turner's (1974) notion of "communitas," understood as a "modality of human interrelatedness" that leads to "deep . . . personal interaction" (p. 76) among individuals without much interference by social structures. By virtue of their existence and their production and sharing through global networks, holy selfies have the power to convey insights into the formation of contemporary quotidian Muslim identities. As such, they beg examination as a space for critical reflections on the issues that Muslims in the 21st century face in their everyday lives. 


\section{Methods}

In order to address the raised issues, we conducted a visual and content analysis of 100 publicly viewable selfies. Sampling units for content analyses included photographs and associated captions and tags posted online on such social media platforms as Iconosquare (an Instagram analytics and organizational tool), Twitter, Flickr, and personal blogs.

Most selfies were collected between January and May 2015 using the search tools available on the respective social media websites and using Google search features. Test searches were conducted between October and December 2014 using Google Images, which led to the identification of several social media websites likely to return usable images and to the refinement of search terms. The testing resulted in the elimination of some social media platforms, such as Tumblr and Reddit, as likely sources of appropriate selfies because only a handful of results were returned. The testing also helped identify the multiple ways in which some desirable search terms, such as Mecca, were spelled in tags (e.g., Mekka, Makkah, Mekke). ${ }^{1}$

Given the global nature of the Hajj (71\% of Hajj pilgrims in 2016 came from outside of Saudi Arabia; "Saudi Arabia," 2016), search terms were limited to English and included Hajj, Mecca, Umrah, Kabba, Selfie, Arafat, and their spelling variations. The method followed a berry-picking approach (Bates, 1989) whereby locating one appropriate photo often led to clicking on a tag for that photo to see if others that were similarly tagged would also be appropriate. Also, search terms were entered into the social media platforms identified above. As appropriate photos were located, they were examined further and set aside for inclusion in the sample until the target number of photos was obtained. During the close examination of the photos and captions, some photos were eliminated based on their image quality or whether they could be categorized as a "true" selfie. One can often identify a selfie because the photographer's arm can be seen extended in the image. However, as selfies do not necessarily show an extended arm and can now be taken with gadgets such as extension poles (known as "selfie sticks"), we had to vet each picture for inclusion in the study.

The 100 selfies in the sample were reviewed by three coders (the co-authors) who each described what they saw in the photographs and collaboratively negotiated the coding and categories. Information recorded about the photos included captions and tags, the number of people in the photo, the gender of persons in the photo, the location shown in photo, the nature of the pilgrimage (the Hajj or the Umrah), the estimated age of persons in the photo (defined as a range), the facial expression, the URL, and other general notes that might be relevant. Such features as the facial expression, gender, and age of the subjects have also been analyzed in other selfie research projects (Selfiecity, 2014).

Like other studies that use visual methods, we relied on image as "evidence" (Rose, 2012) and took a thematic approach to identify, analyze, and represent patterns and themes emerging from the data. A deductive form of theoretical thematic analysis was applied to the examination of the selfies based on theories, concepts, and trends in information behavior and new media research. While our analysis embraced the surface reality of the selfies, where available, we complemented it with the textual information that accompanied the selfies. The additional data (tags, comments, captions) were helpful in contextualizing the selfies and getting to the meaning-making of the pilgrims.

The nature of the pilgrimage (the Hajj or the Umrah) was determined mainly through the textual information accompanying the photo; however, in some cases it was inferred from the clothing, 
particularly the Ihraam, or distinctive white garment worn by men during the Hajj, or the compulsory haircut noticed in male selfies. Similarly, the exact location of the photograph was not always possible to determine unless it was indicated by the caption or tagging. At a minimum, the coders recorded whether the photo was taken indoors or outdoors if that was discernible. Because facial expression could be largely subjective, the coding was limited to "smiling" or "no expression" (indicating no smiling or other obvious expression). Through tagging and captions, details about the location, the purpose of the selfie (e.g., personal information management, commenting on the Hajj), the identification of companions, the stages of the ritual, and the nature of the pilgrimage (the Hajj, the Umrah, etc.) were determined.

\section{Findings}

As the main object of a selfie is to depict the image of oneself, we examined the photographs and categorized the sample along the lines of the one-person selfie versus dyad or group selfie, as shown in Table 1. In this table, we also included the gender distribution to get a sense of how gender plays out in holy selfie-taking in our sample.

\begin{tabular}{ll}
\hline Individuals depicted & Number \\
\hline Male alone & 47 \\
Female alone & 8 \\
Dyad: male/male & 12 \\
Dyad: female/female & 7 \\
Dyad: male/female & 10 \\
Group of 3+ males & 9 \\
Group of 3+ females & 3 \\
Mixed group (males/females) & 4
\end{tabular}

Table 1. The type of selfie (individual or group) and the gender distribution.

According to the Saudi Press Agency, a total of 1,862,909 people performed the Hajj in 2016. Of these, male pilgrims made up 1,082,228 (58\%) of the total pilgrims while female pilgrims represented 780,681 (41.9\%). Our sample of selfies depicted significantly more males (single as well as in dyads or groups), with $68 \%$ of cases in the sample compared with the $18 \%$ of selfies depicting females. Mixed group depictions account for $14 \%$ of selfies, often portraying a (presumably) married couple or an intergenerational family. ${ }^{2}$ Generally speaking, during our selection process, we noted that the total number of selfies depicting males far outweighed the number of female selfies. Our selected sample reflected these trends. These findings run against many studies and the overall conception in pop culture that situate selfie-taking as a predominantly female practice. The Pew study (Pew Research Center, 2014), for instance, found that women are more likely than men to have posted a selfie. While the selfie phenomenon is ingrained in youth culture, it is not clear whether women take many more selfies than men, despite the common belief. What may be clearer is that popular selfie discourse tends to identify

The International Journal of Information, Diversity, \& Inclusion, 2(1-2), 2018 ISSN 2574-3430, publish.lib.umd.edu/IJIDI/ 
selfies as feminine and has a disciplinary and devaluing effect on selfie-takers, particularly young women (Burns, 2015). Lövheim (2004) posits that online interaction might maintain the relations of power based on gender or race found in offline contexts. Further research is required about associations between the motivations and the gender of posters. Possible explanations may have to do with the transnational character of the pilgrimage and how it translates into the local cultural and media practices. Other possible explanations may have to do with the culturally and historically contingent understanding of "modesty" for women in Islam and its interpretation in a digital environment. Moreover, pressures to manage impressions and honor in some Muslim societies-also culturally and historically contingent and not universal to all Muslim women-tend to be especially felt by women due to the greater behavioral restrictions they face (Pearce \& Vitak, 2015).

\section{Age}

While this exercise is at best approximative, we deemed it helpful to pay attention to the range of individuals who partake in the practice of holy selfies. Table 2 shows the breakdown.

\begin{tabular}{ll}
\hline Age groups (range) & Number of individuals depicted \\
\hline Children (14 and younger) & 6 (3 males, 3 females $)$ \\
Teens/young adults (15 to mid-20s) & 91 (60 males, 31 females) \\
Adults (late 20s and older) & 77 (63 males, 14 females) \\
Older adults (60+) & 6 (1 male, 5 females) \\
\hline
\end{tabular}

Table 2. The group distribution by age.

While there is a multigenerational representation of individuals in our sample of holy selfies, most of them seem to be taken by younger Muslims: Out of the total number of depicted individuals $(\mathrm{N}=180), 97(53.89 \%)$ belong to the millennial generation. We could say that while adults and older adults are not excluded from participating in selfie culture, this phenomenon remains more popular with young people. It is important to note, however, that the pilgrimage is touted as a once-in-a-lifetime journey and remains a costly endeavor, which could also explain why those who can afford to complete the Hajj tend to be in the middle age range. However, it is also true that because the Umrah-the less formal pilgrimage-does not imply a specific time frame and does not entail the higher costs associated with the Hajj, it is likely that families, including younger children, would be more likely to visit the holy sites during the Umrah.

\section{Pilgrimage Depicted}

Table 3 shows the breakdown of selfies in terms of the Hajj versus the Umrah. In some instances, it was unclear from the picture, tags, or accompanying captions which of the two pilgrimages the picture depicted. In most instances, however, we were able to infer from the context whether the selfie depicted the Hajj or the Umrah. Clues included the tags, the depiction of the men's white off-the-shoulder garment, or the time of year the picture was taken (the Islamic calendar is lunar and, as a result, the Hajj takes place at different times each year). It seems that while pilgrims do engage in selfie-taking during the more symbolic and ritualized Hajj (33\%), a greater number (53\%) of the Umrah pilgrims engaged in this practice. The growing popularity 
of the shorter, less regulated Umrah, which can be completed throughout the year, may explain the greater number of selfies (Bianchi, 2017). The $14 \%$ that constitute the unknown category consist of pictures where the context, garments, or accompanying information could not give us a clue as to what pilgrimage the individual was engaging in.

\begin{tabular}{ll}
\hline Nature of the pilgrimage & Number \\
\hline Hajj (explicitly stated) & 25 \\
Umrah (explicitly stated) & 31 \\
Hajj (inferred) & 8 \\
Umrah (inferred) & 22 \\
Unknown & 14 \\
\hline
\end{tabular}

\section{Location}

A recurrent theme in holy selfies is location (see Table 4). Mecca was the location of choice for over $63 \%$ of the selfie-takers. The Kaaba, a cube-shaped structure that is among the holiest symbols in Islam (also known as "Bait-Allah," the house of God, built by the prophet Abraham), was represented in $34 \%$ of all selfies taken. The Kaaba is a recurrent image in holy selfies and appears as a central part of the composition of the selfie. For example, when the selfie is taken from a hotel room, the camera is directed to capture the Kaaba in the background. Second to the Kaaba is the other holy site of Masjid al-Haram, the large mosque including the Kaaba. While less immediately recognizable, it seems to be nonetheless a favored selfie-taking location for pilgrims. Lastly, the holy site of Mount Arafat, recognizable by its bare and rugged landscape, is another popular location where selfies are taken. Besides identifiable sites that have religious and spiritual significance, other sites for talking selfies include hotel rooms, airports, and other public transit sites. The anonymity of such locales seems to provide a good alternative for those reluctant to take selfies at holy sites but still wishing to document their pilgrimage journey. It is also a depiction of the transition/passage state, both literally and symbolically.

\section{Language Used}

Given the importance of the pilgrimage site and its symbolism in Islam, along with the diverse tapestry that reflects global Islam-with 71\% of all Hajj pilgrims in 2016 coming from geographic regions outside of Saudi Arabia ("Saudi Arabia," 2016)-it comes as no surprise that there is a diversity of languages accompanying selfies, as noted in the tags, captions, and accompanying text. The breakdown of languages used is shown in Table 5.

In our sample, English is used in $75 \%$ of the selfies, while the remaining $25 \%$ had accompanying text in languages other than English.

We must note that the search for selfies in this sample was done in English and that some countries use other terms to refer to selfies (e.g., "selka" in Korean, "jidon" in Japanese, "autofoto" in Spanish, and "narsis" in Indonesian). However, the addition of such search terms 
as "Hajj" or "Mecca" (and variant forms of these common words) enabled us to broaden our linguistic pool and capture a wider set of such selfies. Our findings nevertheless show the widespread use of English as a posting language and suggests that regardless of the language they usually speak, holy-selfie-takers prefer to use English when sharing their pictures publicly, perhaps as a means of reaching a wider audience.

\begin{tabular}{ll}
\hline Location & Number of selfies depicting location \\
\hline The Kaaba, Mecca & 34 \\
Masjid al Haram, Mecca & 15 \\
Mecca, other locations & 14 \\
Madinah & 2 \\
Mt Arafat & 12 \\
Jeddah Airport or other airport & 5 \\
Hotel room & 6 \\
\hline
\end{tabular}

Table 4. Locations depicted in the holy selfies.

\begin{tabular}{ll}
\hline Languages used & Number \\
\hline English & 75 \\
Turkish & 12 \\
Indonesian & 5 \\
Malay & 4 \\
Arabic & 4
\end{tabular}

Table 5. Languages used in descriptions accompanying selfies (tags, captions, comments).

\section{Filters}

We also examined the use of filters in our sample of selfies to determine their prevalence on social media sites. New picture-focused platforms such as Instagram give the user the option to apply a filter-that is, to overlay one of several different pre-made light and composition settings on the picture in order to give it a different appearance or feel. It is worth noting that smartphones have also begun offering filtering options, which makes the use of filters more prevalent.

Our data analysis indicates that at least $55 \%$ of the selfies analyzed have been modified, ranging from very subtle light changes to a heavier manipulation of the image. By going back to the source of the picture, we were also able to see evidence of staging when multiple versions of 
the selfie were shared by the poster. We estimate at least $55 \%$ because some filters are very soft and it was difficult to be absolutely certain. Despite these limitations, the results point to the posters having a high level of engagement with their selfies, including the care and attention displayed by many posters with regard to the aesthetics of what they posted; it can be referred to as self-fashioning in order to ensure that what they post is not only informative but also visually appealing.

\section{Captions, Hashtags, and Trending Topics}

Most analyzed images were accompanied by a variety of captions or hashtags that helped us collect additional information, such as location, date, or overall comments by the person posting the holy selfie. In addition to using said tags as a tool to find and categorize the 100 selfies, they helped us establish further the possible motivations that the poster had when sharing the picture.

\section{Hashtags}

The practice of introducing a pound (\#) symbol before a word started in 2007. It was a feature offered by Twitter to organize content into categories and create a link inside the post so that it can be searchable. A search on a specific hashtag would bring up a real-time feed of all posts mentioning the subject. Since then it has expanded to other social media platforms, including Instagram.

As expected, some of the most popular hashtags used in our sample of holy selfies were related to the pilgrimage itself or to the journey itself, along with self-referential hashtags (i.e., \#selfie). The most popular hashtags are shown in Table 6. Different spellings and variations were coded together under one heading.

\begin{tabular}{ll}
\hline Hashtag used & Number \\
\hline \#Mekkah & 50 \\
\#Hajj & 34 \\
\#Umrah & 28 \\
\#Kaaba & 19 \\
\#Selfie (also & 12 as an explicit hashtag, 15 times \\
considered \#me) & as plain text in the caption. \\
\hline
\end{tabular}

Table 6. Most popular hashtags used to describe selfies.

The most prevalent tags refer to the purpose of the journey (Hajj or Umrah pilgrimages) and the location (Mecca, Kaaba, etc.). In the case of the "Kaaba" tag, it can be construed as both a physical reference as well as a symbolic one that stands for the whole journey. Other recurring tags referred to the mood or feelings of the poster at the time (e.g., \#blessed, \#sothankful, \#happy, \#cold, and \#cried) and, by extension, the experience and impact of the pilgrimage for the poster.

The role of hashtags on Instagram is not only to categorize posts, but also to maximize exposure 
and get more followers and likes. Tagging a picture with several popular categories, regardless of its actual content, guarantees that other users in addition to followers will find and view the picture, thus giving it more exposure. Social media users (and Instagram users in particular) appear to give great importance to the status and number of their followers and the interactions on their posts, which would make this use of hashtags one of the possible tools to acquire status in the social network.

In our holy selfies sample, we found that $76 \%$ of the pictures have at least one hashtag. Of those, $62 \%$ use between 1 and 5 hashtags per post, while the remaining 38\% use between 6 and 25 hashtags per post. Those using multiple hashtags (e.g., one picture had 25 hashtags) tend to create the "follower traps" described above. Hashtags serve to give global access to images shared on social media.

\section{Trending Topics}

Trending topics are those that are being discussed more than others. When a topic is trending, posts using associated keywords appear on a common feed. Every user can weigh in on the conversation or topic. In our holy selfies study, we found one instance of a selfie showing two young veiled females with the hashtags \#Mecca and \#Hajj2013 along with the caption "Just an average day in the life of a Muslim." Nothing in the background of the selfie offered any other visual clue. Upon closer analysis, however, we noticed that the girls were wearing what looked like two patterned blankets as headcovers. While tracing the poster of the selfie (one of the two depicted girls on the selfie), we discovered that she was a teenage American girl with no apparent links to Islam. The only explanation we could come up with is that, at the time when the picture was taken and posted, both \#Mecca and \#Hajj2013 were trending worldwide, perhaps causing the girls to stage the picture as a means of piggybacking on the trending topic of the day. This phenomenon speaks to the cultural implications that social networks like Twitter can have, and we opted to keep that selfie as part of our sample to illustrate this phenomenon.

\section{Captions}

In contrast with hashtags, captions have a more personal and descriptive feel to them. Selfietakers use captions to identify their location or comment on their surroundings (e.g., "inside the airplane" or "Kaaba"). Captions were also used to further describe one's pilgrimage experience including one's feelings, their company at the time, or the mood of the moment. We analyzed and coded separately the captions accompanying the holy selfies as a means of grasping the state of mind and motivations of the poster when uploading the picture. Below are the categories under which the analyzed captions fell; they are not mutually exclusive.

We distinguished between the two types of captions: ones that are used to document a pilgrim's journey, categorized as "Documenting Travel," and ones that are more self-referential and address the process of taking a selfie, sharing it, or attracting followers and likes, categorized as "Meta-Comment."

The "Documenting Travel" category considered all the comments made by the posters when referring to the journey itself, both in a physical and in a spiritual way. The main purpose of this category seems to be about writing oneself into the place, space, and time of the pilgrimage by capturing and creating memories from one's journey to the Hajj or the Umrah. Within this category, we identified three subcategories: "Contextual Factors," "Company," and "PsychoSpiritual Expressions." The contextual factors refer specifically to the location, time, and stage 
of the ritual, activity, etc. (e.g., "at the Kaaba," "it's a bit \#cold today in \#Mecca," and "Having completed our first day at Makkah"). Under "Company," we included any mentions of other people who were referred to by the posters (e.g., "Having another selfie, now with Sheikh at the front of Masjid Nabawi," "Me n zila for my last umrah year 2012," and "Look how beautiful it is and look at all the ppl \#mecca \#Kaabah"). Captions were also used to point to people who were not physically present at the time of the selfie-taking as an acknowledgment or a reminder. For example, in one selfie there is a long caption from the poster thanking her dad for the trip, but the dad is not present in the picture. Other selfies use the hashtag \#wishyouwerehere (e.g., "After Eshaii prayer in the Haram! \#wishyouwerehere with us! \#Makkah").

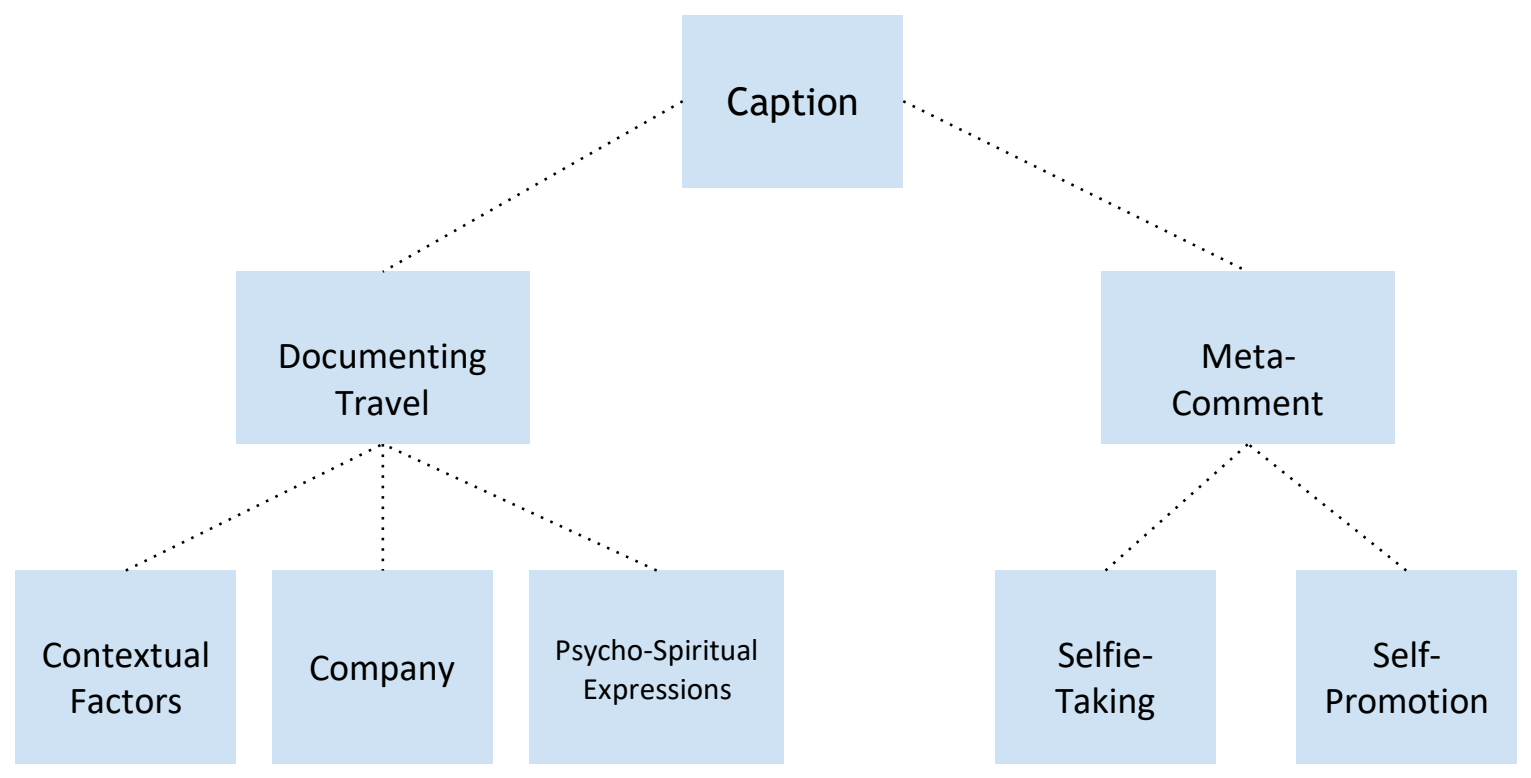

Figure 1 . The categorization of the captions accompanying the holy selfies.

Hashtags give wide access to relevant, socially shared images, which suggests that these pilgrims mean for their spiritual journeys to be found and seen. In using hashtags, these individuals are sending several messages: They are clearly positioning themselves as Muslims for both Muslim and non-Muslim audiences. They also come across as devout enough and/or financially able to undertake the pilgrimage. Similarly, they become a de facto member of the community of pilgrims of all faiths who are documenting their journeys online. Lastly, they are sending a message about their relationship to technology, digital culture, and social media literacy. Through this self-expression, pilgrims seem to resist past and current stereotypes and find instead their own voices. As such, the holy selfie resists not only orientalist representations but also certain stigmas within Islamic communities, for example, the fatwa against the use of technology at the Hajj or political suppression of mass-Muslim voices. ${ }^{3}$

"Psycho-Spiritual Expressions" refers to the affective and spiritual dimensions of the person's experience at holy sites. Contrary to the Contextual Factors subcategory, Pyscho-Spiritual Expressions focuses entirely on comments about the posters' inner states, emotions, and meaning-making triggered by pilgrimage experiences and the associated personal growth. In this subcategory, we found an array of expressions of the spiritual significance of the event for the pilgrim/poster, including expressions of gratefulness and awe, invocations, recitations, and 
prayers (see also Schnell \& Pali, 2013; Warfield, Baker, \& Parikh Foxx, 2014). The poses people strike in many selfies, at times smiling at the camera and at times gazing impassively, add a layer of meaning. Selfie authors appear to be actively working on their self-representation rather than leaving their captured images to chance. The holy selfie indicates a very deliberate participatory decision on the part of the selfie-taker, that of engaging and challenging the voyeur by means of a direct gaze into the camera.

Tags and captions also shed light on the meaning-making that pilgrims seem to engage in as they retrace their journeys as individuals but also as members of a broader faith community. Some selfies are posted not in real time but upon one's return from the Hajj/Umrah, and they are often imbued with nostalgia and point to people's reminiscing about their pilgrimage (e.g., "I miss that place already" and "It's been a while since I did this.. . \#tawaf \#umrah \#Alhamdulillah"). Several selfies included a stream of tags such as \#fun, \#love, \#smile, \#beautiful, and \#life. One selfie was explicitly hashtagged with \#tbt (acronym for "throwback Thursday"), which has been gaining popularity on such platforms as Instagram and is generally used when uploading a picture and letting followers know that it is not something currently happening, but rather a tribute to an event that happened at an earlier time but that they want to share now-or again-with their followers.

The "Meta-Comment" category was devised to classify all the captions that referred to the making of the selfie (e.g., "The final ritual of Hajj . . . a selfie \#hajjselfie" and "selfie of the year with the Kaaba \#mecca \#saudiarabia \#umrah") or the equipment used (e.g., "Nokia N95 8GB"). We must not forget that selfies, while being an important part of youth culture, are still somehow stigmatized, even by youth themselves, as something shallow and vain (Murray, 2015; Wallop, 2013).

Selfies are also made for public consumption, and we see the evidence of self-promotion and attention paid by holy selfie posters to attract more followers. Three posters, for example, captioned their holy selfies with the line "but first, let me take a selfie." This is a direct reference to the band "The Chainsmokers," which released a single called \#Selfie that repeatedly used that specific line. Interestingly, the song both mocks selfies and praises them as an important part of today's youth culture. The line has since become part of the vocabulary of youth and popular culture. The social media proficiency of many holy selfie posters when it comes to getting exposure and audience engagement (through the use of hashtags, for example) has been mentioned already. In addition to hashtags and captions that documented one's location or state of mind, several selfies in our sample used such tags as \#instaislam or \#likeforfaith. To add the prefix "insta" before any word has become a widespread hashtag practice inside the Instagram community and facilitates the search and retrieval of related topics (\#instafood, \#instalove, etc.). \#Likeforfaith demonstrates another popular practice: adding a term after \#likefor"; this practice is evidence that some holy selfie posters are familiar with the culture and mechanisms necessary make a picture go viral.

Last but not least, we noted a dozen instances of celebrity selfies in our sample, including an Egyptian soccer player, a fashion blogger with over 100,000 Instagram followers, a Pakistani TV and film star, a Pakistani cricket player, and several Indonesian movie stars. For such pictures, the audience response, through comments, likes, retweets, and so on, was significantly higher. It must be noted that these celebrity selfies were often posted by third parties who talked about said celebrities rather than by the celebrities themselves. 
Selfies, along with their associated tags and captions, suggest that there is much conscious and active work put into this social media practice. In the case of holy selfies, we have seen that they are designed both for public consumption (e.g., self-fashioning, tagging, filtering) and as the evidence of pilgrims' religious positioning and membership. The pilgrim is immediately recognized as Muslim, which is an important consideration for Muslims living in the West post9/11. Moreover, holy selfie posters position themselves as digitally literate by virtue of being social media producers and consumers. This also places them at odds with more conservative voices in Islam that decry or prohibit the use of social media. Holy selfies, through their production and consumption, can therefore reveal much about identities, affiliations, relationships, and status.

\section{Discussion}

Our visual and textual analysis of the 100 selfies taken at the Hajj and the Umrah points to several important findings. First, many pilgrims do not see selfie-taking as inherently wrong or disconnected from their broader spiritual journey. While investing time into taking and uploading photos may seem to defy the pilgrimage tradition of detaching from the world, completing a set of rituals, and engaging in self-reflection and spiritual growth, it is clear that many pilgrims view selfie-taking as an important part of their journey. Specifically, there seems to be great pleasure derived from writing oneself into holy sites and from capturing, annotating, and sharing these fleeting moments. The embodied experience of pilgrims at holy sites seems to find an expressive release through holy selfies. The photographs seem to have the power to transport the poster and the viewer back to the state that the poster experienced during the Hajj or the Umrah. Our analysis suggests that pilgrims use the selfies and associated features for the purpose of capturing and documenting their experience, making sense of their spiritual journey, sharing memories with loved ones and like-minded fellows online, and participating in social media practices, including self-fashioning and attracting followers.

Second, more pilgrims (53\%) took selfies during the Umrah pilgrimage as opposed to the more symbolic and ritualized Hajj (33\%). The Hajj may be perceived to be more formal in nature given its significance, as well as more crowded, with over two million Muslims converging each year at holy sites (Bianchi, 2017, p.7). The disapproving looks from fellow pilgrims and the presence of security personnel discouraging pilgrims from slowing down others at the most photographed sites, including the Kaaba, may have something to do with the lower prevalence of selfies during the Hajj. If the Umrah is more akin to tourism and the Hajj to a more formal pilgrimage, then it stands to reason that an element of censorship might be at play whereby pilgrims may deem it more acceptable to engage in selfie-taking during the Umrah than the Hajj. This would denote a shared sense of what is and is not appropriate in this religious pilgrimage context. Even the visual aesthetics are surprisingly consistent. Through the selection and depiction of particular Islamic sites and symbols (the Kaaba, Mt. Arafat, Masjid al Haram, the white ihram garments, men's shaven heads, and women's headcovers, to name just a few), holy selfies devise specific narratives about pilgrims' performance of the Hajj/Umrah. The very framing of selfies leaves out other concerns, such as consumerism and class differences (Bianchi, 2017). Indeed, one need only step a few hundred meters outside the precincts of the Kaaba and the Holy Mosque to find international chains (Starbucks, McDonald's, KFC), five star hotels with WiFi and air conditioning, and high-end luxury retailers and malls. Yet, these symbols are hardly ever captured in the analyzed holy selfies. The tension between the spiritual and the material is not new: Mecca has always been a booming trading center, and gift-giving upon a pilgrim's return is, after all, a common practice (Bianchi, 2004; Porter, 2012). Yet, what is framed and projected by holy selfies 
for public consumption focuses instead on the religious symbols and signs that evoke the solemnity of the experience, leaving aside mundane, material, and touristic aspects of the journey. In that sense, holy selfies seem to be filtered through a shared lens based on what is considered appropriate from a religious perspective.

When it comes to who engages in the holy selfie practice, our data show that holy selfies tend to feature as many males as females. These findings diverge from those of some other studies and from the overall conception in popular culture, which situate selfies as an activity most popular with teenage girls. Indeed, much discourse around selfies is about selfie-taking by adolescents in general and young girls in particular, and a frequent argument is that young girls engage in selfie-taking for narcissistic reasons (Murray, 2015; Wallop, 2013). Given the diversity of the Muslim world and Muslim experience, more data need to be collected about the prevalence of smartphones and mobile data plans among men and women. Further research, including through in-depth interviews, would help elucidate the motivational aspect of selfie-taking. Also needed is further research on the concept of modesty or honor as it applies to women in Islamic religious settings (Echchaibi, 2013; El Guindi, 1999; Hajjaj-Jarrah, 2003; Pearce \& Vitak, 2015) to determine how it may extend to sharing personal photographs publicly on social media.

Our study demonstrates the emergence and significance of holy selfies; it shows the importance of holy selfies in producing and sharing these images among selfie takers. The mere existence of holy selfies and the careful construction of these images are significant. From the location to the camera angle and from the editing of the picture to the application of hashtags and captions, holy selfie takers clearly intend their pictures to be viewed and consumed publicly. A legitimate question then is the extent to which selfies might be assumed to be directed toward non-Muslims as well as Muslims. We argue that holy selfies as an emerging practice may well contribute to building an alternative representation of Muslims and the Islam that stems from the media and popular culture. Barry Flood (2016), for example, contends that the construction and circulation of images of Islamic power are often expressed through contemporary forms of iconoclasm (in relation to ancient monuments, for instance). Holy selfies seem to focus on the positive and constructive images rather than the negative and destructive ones. By putting the person rather than the place in the foreground (though the assumed presence of the latter is crucial), holy selfies thus populate the imagined and virtual space of the Internet with very different images of Islam. In the absence of testimonies by those who make these selfies, it is difficult to know how deliberate this "alternative" production is. Regardless, holy selfies tell us something about the centrifugal power of images of Islam mediated through the actual bodies of Muslims, which, ironically, can only be produced by the centripetal act of going to Mecca in the first place.

The intended audiences for selfie consumption are clearly multiple, as we have surmised, and it would be interesting to examine the opportunities for community building enabled by holy selfies and the necessity for building such communities. In theoretical terms, the phenomenon of holy selfies finds meaning in Gell's (1998) idea of distributed personhood whereby the locus of the pilgrims' agency (in this case) goes beyond their bodies and includes the images and artifacts produced. The taking of selfies can be seen as part of a wider set of visual and non-mediated practices that characterize today's everyday lived religion. In Islam, such contemporary visual practices are exemplified by the popularity of preachers like Amr Khaled, ${ }^{4}$ for instance. Unlike the colonial postcards of the 1930s, the self-produced images of Islamic places and Muslim people suggest a disruption of the traditional image-voyeur relationship. Global access to the holy selfie does not lower the risk of reproduced orientalist stigma (as our example of the faux holy selfie account demonstrates), but it does provide a fearless account of the active revealing and circulating of free religious agency through the holy selfie sub-genre. This object agency is 
performed in both authorship and reproduction of the image, with little to no interference or intermediation by an othering discourse. Through their self-revealing, pilgrims resist past and current representations and acts and voluntarily insert themselves into the same global social media archive (see also Echchaibi, 2013; Hirji, 2006). When looking at the holy selfie, or selfies in general, one cannot but insert the context, subjects, and locations among other political and social spectrums/multiplicities. As Wells (2003) points out, speaking of photography, "still images have to been seen as inter-related to other media forms (television, advertising, radio soaps, newspaper features ... .) [and] as sites within which particular ideas tend to be reinforced" (p. 376). As we saw with the trending topic, the popularity of the holy selfie allows and encourages others to do the same. My Stealthy Freedom serves as an important example of the resistive power of the reproduced selfie sub-genre. For marginalized persons, selfies serve as an instrument of resistance and a chance to actively shape how Muslims are seen, instead of having their images created on their behalf and without their participation.

Although the pilgrims may take selfies as part of their everyday encounters, the holy selfie posits a very deliberate participatory decision. Near the Kaaba and in the selfie itself, selfie-takers are surrounded by hundreds of others participating in a common journey. The holy selfie, through its power to negate social hierarchies and consumerist references, works to present the image of a Muslim person in a subjectively unified way. In this case, unification is not achieved through the homogeneity of people, because the Muslim population is incredibly diverse; rather, unification occurs through the inclusive religious acts of \#Hajj or \#Umrah. The holy selfie becomes itself a performance of Islam. While publicly inscribing the individual as a believer and as a Muslim, devout and privileged enough to undertake the pilgrimage, holy selfies lend a voice to individuals. They grant pilgrims the power to articulate the meaning of the pilgrimage for themselves without having to appease the outside onlookers (e.g., the male gaze, the non-Muslim gaze, the Muslim extremist gaze, and the anti-Muslim gaze). In that respect, they are a useful tool that enables the individual to construct a more complex picture of what it means to be a Muslim in the 21st century, a picture whereby being Muslim becomes one of the many identity layers. More generally, our examination of holy selfies suggests that they are a space for selfrepresentation and critical reflections on the issues that 21 st-century believers of all faiths, and Muslims in particular, face in their everyday lives. This echoes Echchaibi's (2013) study of women bloggers on Muslimah Media Watch where the blogging became an instrument to respond to their absence in simplistic western discourse and their invisibility in mainstream Muslim narratives. Their blogging represents an act of performing their gendered and religious self in a way denied to them by dominant power structures (p. 865)

\section{Conclusion}

While photographs have always been taken during the Hajj and the Umrah despite the prohibition, the networks of distribution and dissemination limited the reach of these photographs. In the case of holy selfies, a quick Google search turns up countless pictures of individual Muslims (men and women) who partook in the pilgrimage. The transnational character of the holy selfies practice reveals the significance of the religious Hajj/Umrah narrative. Pilgrims embark on the Hajj and the Umrah for a variety of reasons (a search for redemption, authenticity, or communitas) and usually return transformed.

Social media platforms are fostering environments where individuals of all faiths can express their ideological and religious identities by performing, or "doing," religion rather than relying on the various "others" to speak on their behalf. The power to represent oneself is critical for 
Muslims who are constantly spoken for and about and are unable to construct an identity of their own. Viewing holy selfies as a manifestation of Muslims' expression of their everyday lived religion takes us a step closer to appreciating the complexity involved in the formation of contemporary Muslim identities.

\section{Acknowledgements}

The authors thank Dr. Simon Coleman, Dr. Leslie Shade, Dr. Keren Dali, Dr. David Simonowitz, Mariam Karim, and the reviewers for their helpful comments. This article carries many suggestions and ideas from them. We cannot thank them enough. Omissions and errors remain our own.

\section{Endnotes}

${ }^{1}$ We note the variation in spellings of Arabic terms used in this article (Mecca, Makkah; Umra, Umrah; Medina, Madinah). While acknowledging these variant spellings, we have sought to maintain consistency and therefore use "Mecca," "Hajj," and "Umrah" throughout the article.

${ }^{2}$ A woman performing Hajj is required to be accompanied by a Mahram (usually a spouse or close male relative such as a brother, son, uncle, or father). This practice, however, is increasingly reexamined. Saudi embassies even mention in the Hajj requirements FAQs that women over the age of $\mathbf{4 5}$ may travel without a Mahram with an organized group. Some Hajj tour groups also openly advertise this feature on their website (https: / / www.saudiembassy.net/hajj-requirements).

${ }^{3}$ A fatwa is "a legal opinion or decree handed down by an Islamic religious leader" ("fatwa," n.d.)

${ }^{4}$ Amr Khaled is an Egyptian televangelist listed as one of the "100 men and women whose power, talent or moral example is transforming the world" (Nomani, 2007).

\section{References}

AFP. (2014, October 5). Hajj selfies cause controversy among conservative Muslims. The Telegraph (U.K.). Retrieved from http://www.telegraph.co.uk/news/worldnews/middleeast/saudiarabia/11141770/Hajj -selfies-cause-controversy-among-conservative-Muslims.html

Agger, B. (2012). Oversharing: Presentations of self in the Internet age. New York: Routledge.

Aneja, A. (2014, October 3). Hajj 2014: The year of the selfie. Time. Retrieved from http://time.com/3462348/hajj-2014-the-year-of-the-selfie/

Appadurai, A. (1986). Introduction: Commodities and the politics of value. In A. Appadurai (Ed.), The social life of things: Commodities in cultural perspective (pp. 3-63). Cambridge: Cambridge University Press. 
Bates, M. J. (1989). The design of browsing and berrypicking techniques for the online search interface. Online Review, 13(5), 407-424.

Bhabha, H. (2007). The other question: The stereotype and colonial discourse. In J. Evans \& S. Hall (Eds.), Visual culture: A reader (pp. 370-379). London: SAGE Publications.

Bhimani, S. (2013). Mapping the assembly of Muslim exceptionality and exceptional Muslims: Ismaili Muslim encounters through discourses, bodies and space in the Canadian colonial nation. Doctoral dissertation, University of Toronto.

Bianchi, R. R. (2004). Guests of God: Pilgrimage and politics in the Islamic world. Oxford: Oxford University Press.

Bianchi, R. R. (2017). Reimagining the Hajj. Social Sciences, 6(36), 1-26. Retrieved from http://www.mdpi.com:8080/2076-0760/6/2/36

Blumberg, A. (2014, October 1). Infamous Hajj selfie is one more thing transforming Mecca, and not everyone is happy about it. Huffington Post. Retrieved from http://www.huffingtonpost.com/2014/10/01/hajj-selfie_n_5915054.html

Boutcher, W. (2013). Literary art and agency? Gell and the magic of the early modern book. In L. Chua \& M. Elliott (Eds.), Distributed objects: Meaning and mattering after Alfred Gell (pp. 155-175). New York: Berghahn Books.

Burns, A. (2015). Selfies| self(ie)-discipline: Social regulation as enacted through the discussion of photographic practice. International Journal of Communication, 9(18), 1716-1733. Retrieved from http://ijoc.org/index.php/ijoc/article/view/3138

Caidi, N., \& MacDonald, S. (2008). Information practices of Canadian Muslims post 9/11. Government Information Quarterly, 25(3), 348-378.

Cep, C. N. (2013, July 15). In praise of selfies. Pacific Standard. Retrieved from http://www.psmag.com/culture/in-praise-of-selfies-from-self-conscious-to-selfconstructive-62486?src=longreads

Dessing, N., Jeldtoft, N., Nielsen, J., \& Woodhead, L. (Eds). (2014). Everyday lived Islam in Europe. Burlington, VT: Ashgate.

Edensor, T. (1998). Tourists at the Taj. London: Routledge.

Echchaibi, N. (2013). Muslimah media watch: Media activism and Muslim choreographies of social change. Journalism, 14(7), 852-867.

Eler, A. (2013, July 1). Take a good look at your selfie. Hyperallergic. [Blog post]. Retrieved from http://hyperallergic.com/73389/take-a-good-look-at-yourselfie/

El Guindi, F. (1999). Veil: Modesty, privacy and resistance. New York: Berg and Oxford International.

Fausing, B. (2013). Selfies and the search for recognition. See for your selfie. Retrieved from http://www.scribd.com/doc/167602342/Selfies-and-the-Search-for-Recognition-See- 
for-your-Selfie

Fatwa. (n.d.) In Merriam-Webster online. Retrieved from http://www.merriamwebster.com/dictionary/fatwa

Flood, D. B. (2016). Idol-breaking as image-making in the "Islamic State." Religion and Society: Advances in Research, 7, 116-138.

Fores, B. (2013, August 12). For girls, Facebook selfies are un-Islamic, say clerics. Rare. Retrieved from http://rare.us/story/for-girls-facebook-selfies-are-un-islamic-sayclerics/

Fox, J., \& Rooney, M. C. (2015). The dark triad and trait self-objectification as predictors of men's use and self-presentation behaviors on social networking sites. Personality and Individual Differences, 76, 161-165.

Freedland, J. (2013, November 19). The selfie's screaming narcissism masks an urge to connect. The Guardian. Retrieved from http://www.theguardian.com/commentisfree/2013/nov/19/selfie-narcissism-oxforddictionary-word

Gani, A. (2015, July 14). Mecca worshippers stream their stories live on Snapchat. The Guardian (online). Retrieved from https://www.theguardian.com/technology/2015/jul/14/mecca-worshippers-streamlive-snapchat-twitter

Gell, A. (1998). Art and Agency. Oxford: Clarendon Press.

Grabar, O. (2006). Islamic visual culture, 1100-1800. Burlington, VT: Ashgate.

Gruber, C., \& Shalem, A. (Eds). (2014). The image of the Prophet between ideal and ideology: A scholarly investigation. Berlin: De Gruyter.

Gruber, C. (2009). Between logos (kalima) and light (nur): Representations of the Prophet Muhammad in Islamic painting. Muqarnas, 26, 1-34.

Guessoum, N. (2011, November 8). New media and Islam. The Huffington Post. Retrieved from http://www.huffingtonpost.com/nidhal-guessoum/new-media-andislam_b_1077496.html

Hajjaj-Jarrah, S. (2003). Women's modesty in Qur'anic commentaries: The founding discourse. In S. S. Alvi, H. Hoodfar, \& S. McDonough (Eds.), The Muslim veil in North America: Issues and debates (pp. 145-180). Toronto, ON: Women's Press.

Hall, D. (Ed.). (1997). Lived religion in America: Toward a history of practice. Princeton, NJ: Princeton University Press.

Hazaimeh, H., \& Waha, S. (2014, October 13). Selfies “distracting, boastful.” Arab News. Retrieved from http://www.arabnews.com/saudi-arabia/news/643531

Heng, M. (2014, October 8). \#Hajjselfie trends during Haj pilgrimage, angering Muslim scholars. 
The Jakarta Post. Retrieved from

http://www.thejakartapost.com/news/2014/10/08/hajjselfie-trends-during-hajpilgrimage-angering-muslim-scholars.html

Hirji, F. (2006). Common concerns and constructed communities. Journal of Communication Inquiry, 30(2), 125-141.

Hudson, P. (2014, April 9). Keep your after sex selfies to your selfies you creeps. Mirror, U.K. Retrieved from http://www.mirror.co.uk/news/uk-news/keep-your-after-sex-selfies3393610

Janmohamed, S. (2016, September 9). Young Muslims will be experiencing Hajj in a very different way this year. The Independent. Retrieved from http://www.independent.co.uk/voices/hajj-mecca-social-media-snapchat-youngmuslims-very-different-way-a7233426.html

Keen, A. (2014, October 30). Selfies at the Hajj: Is nothing sacred? How tech allows narcissism to run riot. CNN: Inside the Middle East. Retrieved from http://www.cnn.com/2014/10/05/opinion/hajj-selfies-keen/

Kellner, D. (2003). From 9/11 to terror war: The dangers of the Bush legacy. Lanham, MD: Rowman \& Littlefield.

Kwon, Y. J., \& Kwon, K. (2015). Consuming the objectified self: The quest for authentic self. Asian Social Science, 11(2), 301-312.

Ladybits. (2014, July 1). The unassuming selfie that went viral. Retrieved from http://www.refinery29.com/2014/07/70144/iranian-journalist-selfie-scandal

Lattouf, A. (2014, October 5). Hajj selfie fever sweeps through mecca after cell phone ban lifted. SBS. Retrieved from http://www.sbs.com.au/news/article/2014/10/05/hajjselfie-fever-sweeps-through-mecca-after-cell-phone-ban-lifted

Lövheim, M. (2004). Young people, religious identity and the Internet. In L. Dawson \& D. Cowan (Eds.), Religion online: Finding faith on the Internet (pp. 59-73). New York: Routledge.

Makhoul, S. (1998). Unveiling North African women, revisited: An Arab feminist critique of orientalist mentality in visual art and ethnography. Anthropology of Consciousness, 9, 39-48. https: //dx.doi.org/10.1525/ac.1998.9.4.39

Mehdizadeh, S. (2010). Self-presentation 2.0: Narcissism and self-esteem on Facebook. CyberPsychology, Behavior \& Social Networking, 13(4), 357-364. https://dx.doi.org/10.1089/cyber.2009.0257

Meikle, G. (2014). [Review of the books The culture of connectivity: A critical history of social media, by José Van Dijck; Understanding social media, by Sam Hinton and Larissa Hjorth; and The social media handbook, edited by Jeremy Hunsinger and Theresa Senft]. . Media, Culture \& Society, 36(7), 1057-1060. https://dx.doi.org/10.1177/0163443714544861

Moumtaz, N. (2015) Refiguring Islam. In S. Altorki (Ed.), A companion to the anthropology of 
the Middle East (pp. 125-150). Hoboken, NJ: John Wiley \& Sons, Inc.

Muchinsky, S. (2015, January 30). As a Muslim who takes selfies, let me tell you why the idea that Muslims should not to take selfies is insane. xoJane. Retrieved from http://www.xojane.com/beauty/muslim-selfies

Murray, D. C. (2015). Notes to self: The visual culture of selfies in the age of social media. Consumption Markets \& Culture, 18(6), 490-516. https://dx.doi.org/10.1080/10253866.2015.1052967

Ng, N. (2014, December 12). Twitter declares 2014 year of the selfie. CNN. Retrieved from http://www.cnn.com/2014/12/12/tech/twitter-selfie-trend/

Nomani, A. (2007, May 3). Amr Khaled. The 2007 TIME 100. Retrieved from http://content.time.com/time/specials/2007/time100/article/0,28804,1595326_16157 54_1616173,00.html

O'Connor, P. (2014). Hong Kong Muslims on Hajj: Rhythms of the pilgrimage 2.0 and experiences of spirituality among twenty-first century global cities. Journal of Muslim Minority Affairs, 34(3), 315-329.

OUPBlog. (2013, November 19). Scholarly reflections on the "selfie." [Blog post]. Retrieved from http: / /blog.oup.com/2013/11/scholarly-reflections-on-the-selfie-woty-2013/

Panek, E. T., Nardis, Y., \& Konrath, S. (2013). Mirror or megaphone?: How relationships between narcissism and social networking site use differ on Facebook and Twitter. Computers in Human Behavior, 29(5), 2004-2012.

http://dx.doi.org/10.1016/j.chb.2013.04.012

Pearce, K. E., \& Vitak, J. (2015). Performing honor online: The affordances of social media for surveillance and impression management in an honor culture. New Media \& Society, 18(11), 2595-2612. https://dx.doi.org/10.1177/1461444815600279

Pew Research Center. (2014). Millenials in adulthood: Detached from institutions, networked with friends. Washington, DC: Pew Research Center.

Porter, V. (Ed.). (2012). Hajj: Journey to the heart of Islam. London: British Museum Press.

Qayyum, M. (2014, October 16). Hajj 2015: Year of development. The Huffington Post. Retrieved from http://www.huffingtonpost.com/mehrunisa-qayyum/hajj-2015-year-ofdevelop_b_5993126.html

Quraishi, A. J. (2014, September 30). Say no to Haj selfie! Arab News. Retrieved from http://www.arabnews.com/islam-perspective/news/637771

Razack, H. S. (1998). Looking white people in the eye. Gender, race and culture in courtrooms and Classrooms. Toronto: University of Toronto Press.

Rose, G. (2012). Visual methodologies: An introduction to researching with visual materials (3rd ed.). London: Sage. 
Ryan, E. G. (2013, November 21). Selfies aren't empowering. They're a cry for help. Jezebel. Retrieved from http: //jezebel.com/selfies-arent-empowering-theyre-a-cry-for-help1468965365

Ryan, T., \& Xenos, S. (2011). Who uses Facebook? An investigation into the relationship between the Big Five, shyness, narcissism, loneliness, and Facebook usage. Computers in Human Behavior, 27(5), 1658-1664. https://dx.doi.org/10.1016/j.chb.2011.02.004

Saudi Arabia says Hajj 2016 receives 1.8M pilgrims. (2016, September 12). Al Arabiya. Retrieved from http://english.alarabiya.net/en/News/middle-east/2016/09/12/SaudiArabia-says-Hajj-2016-receives-1-8-million-pilgrims.html

Schnell, T., \& Pali, S. (2013). Pilgrimage today: The meaning-making potential of ritual. Mental Health, Religion and Culture, 16(9), 887-902.

Selfiecity. (2014). Selfiecity. Retrieved from http://selfiecity.net/

Senft, T., \& Baym, N. (2015). Selfies introduction-What does the selfie say? Investigating a global phenomenon. International Journal of Communication, 9, 19.

Senft, T. M. (2013). Microcelebrity and the branded self. In J. Hartley, J. Burgess \& A. Bruns (Eds.), A companion to new media dynamics (pp. 346-354). West Sussex: WileyBlackwell. https://dx.doi.org/10.1002/9781118321607.ch22

Shannon. (2015, February 19). Humble your selfie: We heard that there was a fatwa outlawing women's selfies. [Blog post]. Retrieved from http://muslimgirl.net/9913/humbleselfie/

Streib, H., Dinter, A., \& Soderblom, K. (Eds). (2008). Lived religion: Conceptual, empirical and practical-theological approaches-Essays in honor of Hans-Gunter Heimbrock. Leiden: Brill.

Thobani, S. (2003). War and the politics of truth-making in Canada. Qualitative Studies in Education, 16(3), 399-414.

Thornhill, T. (2015, January 27). Muslim cleric declares selfies a sin under Islamic law . . and criticises women in particular for being so "shameless." Daily Mail Online. Retrieved from http:// www.dailymail.co.uk/news/article-2928368/Muslim-cleric-declaresselfies-sin-Islamic-law-criticises-women-particular-shameless.html

Tifentale, A. (2014). The selfie: Making sense of the "masturbation of self-image" and the "virtual mini-me." New York: The Graduate Center, The City University of New York. Retrieved from https://d25rsf93iwlmgu.cloudfront.net/downloads/Tifentale_Alise_Selfiecity.pdf

Tifentale, A., \& Manovich, L. (2015). Selfiecity: Exploring photography and self-fashioning in social media. In D. M. Berry \& M. Dieter (Eds.), Postdigital aesthetics: Art, computation and design (pp. 109-122). London: Palgrave Macmillan.

Turner, V. (1974). Liminal to liminoid, in play, flow and ritual: An essay in comparative symbology. Rice University Studies, 60(3), 53-92. 
Twitter. (2010, December 8). To trend or not to trend. [Blog post]. Retrieved from https://blog.twitter.com/2010/trend-or-not-trend

Wallop, H. (2013). Selfies-How the world fell in love with itself. The Telegraph, Retrieved from http://www.telegraph.co.uk/technology/social-media/10460202/Selfies-howthe-world-fell-in-love-with-itself.html

Wang, Y. (2012). Taiwanese girls' self-portraiture on a social networking site. Doctoral dissertation. Retrieved from http://core.ac.uk/download/pdf/9994909.pdf

Warfield, H. A., Baker, S. B., \& Parikh Foxx, S. B. (2014). The therapeutic value of pilgrimage: a grounded theory study. Mental Health, Religion \& Culture, 17(8), 860-875.

Warfield, K. (2014, January 15). An open letter to mass media explaining, definitively, the meaning of selfies. [Blog post]. Retrieved from

http://www.makingselfiesmakingself.com/an-open-letter-to-mass-media-explainingdefinitively-the-meaning-of-selfies.html

Wells, L. (Ed.). (2003). The Photography reader. London: Routledge.

Zine, J. (Ed.). (2012). Islam in the hinterlands: Muslim cultural politics in Canada. Vancouver, $B C$ : UBC Press.

Nadia Caidi (nadia.caidi@utoronto.ca) is an Associate Professor at the Faculty of Information (iSchool), University of Toronto, Canada. Her research focuses on human information behavior, societal implications of information and communication technologies (ICTs), information policy, and critical and cross-cultural studies. Dr. Caidi has received several grants for her research on information control and the public's right to know in times of crisis. Her current research is situated in the context of global migration and the role that information resources, institutions, and technologies play in the everyday lives of migrant and displaced communities. Caidi was President of the Canadian Association for Information Science (2011) and the 2016 President of the international Association for Information Science \& Technology (ASIS\&T).

Susan Beazley (beazleysue@gmail.com) is a Special Librarian and Research Associate working in Toronto, Canada. She holds a Master of Information degree from the Faculty of Information (iSchool), University of Toronto.

Laia Colomer Marquez (laicolomer@gmail.com is a graduate of the Universidad Iberoamericana in Mexico City, where she earned a bachelor's degree in Communications and Media. She was awarded a MITACS Globalink Research Internship, in 2015, to conduct research with Professor Caidi at the Faculty of Information, University of Toronto. 